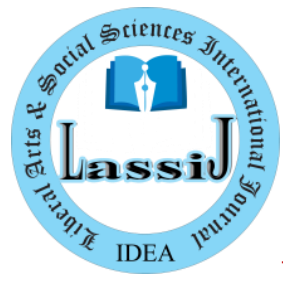

Research Article

ISSN: 2664-8148 (Online)

Liberal Arts and Social Sciences

International Journal (LASSIJ)

https://doi.org/10.47264/idea.lassij/3.2.13

Vol. 3, No. 2, (July-December) 2019, 106-114

https://www.ideapublishers.org/lassij

\title{
Sociological Analysis of Suicide among Female: A Study of Nangarparkar, District Tharparker, Sindh
}

\author{
Shabana Tunio* ${ }^{1}$, Ghazala Shoukat ${ }^{1} \&$ Muhammad Aurangzeb Khan ${ }^{2}$ \\ 1. Department of Sociology, University of Sindh, Jamshoro, Sindh, Pakistan. \\ 2. Department of Social Work, Women University Swabi, Swabi, Pakistan.
}

\begin{abstract}
This research examines the increasing trend of committing suicide in Nangarparkar and its causes. Explanatory research is conducted to find out the causes and trends of increasing suicide rate among female of Taluka Nangarparkar, District Tharparkar, Sindh. Data is collected from twenty respondents which were selected by a purposive sampling method. Data is analyzed in SPSS version 24 and presented in tables and pie charts. The study found that majority of those who committed suicide was between the age group 15-25 years and were mostly illiterate .Marital status shows no significant difference. Majority of female were housewives who committed or attempted suicide. Head of the family was the father. Basic needs were not satisfied and had normal relations with family. $50 \%$ of respondents were not free with their family members and their nature was emotional. 55\% female committed suicide due to domestic violence. Hanging and poisoning were common methods of committing suicide.
\end{abstract}

Keywords: Suicide, Female, Social, Economic, Causes, Psychological, Trends, Nangarparkar.

\section{Introduction}

Suicide is an act or instance of taking one's own life voluntarily and intentionally. Suicide means killing oneself. Emile Durkheim has defended the term as "All cases of death resulting directly or indirectly from a positive or negative act of the victim himself that he knows will produce this result". Suicide is a global phenomenon. It occurs in all societies whether societies are less developed or developed countries of the world. According to WHO Report 2016, in low and middle income countries suicide ratio is $79 \%$. Age wise it is more frequent among 1544 years age group. In current years suicide is increasing worldwide and it is considered third major cause of death.

As declared World Health organization, near about 8 lac people die every year by committing suicide which means in every 40 seconds, one person commits suicide. On age group between 15-29, suicide is the second most important reason of death in the whole world. In 2011, World bank warned Pakistan of increasing suicide rates. In 2008, more than seven thousand cases were reported in Pakistan. Furthermore, there are different socio-e- cultural, economic and psychological reasons of suicide. Many girls commit suicide in Pakistan as they are harassed 
and blackmailed by boys. Many wives commit suicide due to the atrocities caused by their husbands. Poverty and unemployment are one of the major reasons in Pakistan of suicide (Shakil, 2019).

Socio-economic conditions of people of Tharparkar have been assessed by Islamic Relief. Their report indicates the worst situation of District due to draughts. Poverty, low economic status of women, scarcity of food and malnourishment of mother and child and mortality rate are high. Due to shortage of water land is not cultivated and nutritional food is not included in diet of common people (Rahma Islamic Relief, 2015). According to Sindh Study Development Centre (2015) only 33\% land is cultivable in Thar, and 77\% land is deserted. On human development index education, health, housing quality show poor progress in Tharparkar.

This paper examines the trends and causes of suicide among female of Nangarparkar Taluka of District Tharparkar. This study answers following research questions: What is ratio of suicide in Nagarparkar of District Tharparker, Sindh? Why female commit/ attempt suicide? What are socio-economic and psychological causes behind suicide? How suicide rate can be controlled in Nangarparkar, District Tharparker? The hypothesis of the study is:

a) The people socially and economically are vulnerable who committed suicide

b) Most of the people who committed suicide due to poverty and failure in love

Suicide is big social and psychological problem of the world. Many researchers have investigated the issue at national and provincial level in Pakistan. But till now no work has been done on suicide committed/attempted among female of Nagarparkar, District Tharparkar Sindh. Study investigates the socio-economic and psychological causes of suicide among female of Nangarparker, District Tharparker, Sindh. This is very important region in Sindh because it has a majority of Hindu religion, climatic problems as draughts, poverty, illiteracy and political negligence make this region to suffer more. This study had two specific objectives as: (i). To assess the situation of person who committed suicide and (ii): analyse the reason of people to commit suicide.

\section{Literature Review}

Study found that ratio of male is more than female in committinglattempting suicide. Ratio of committing suicide is commonly investigated in Unmarried men and married women. Women especially of age group 30 commits/attempts more suicide. (Khan et al., 2000).Unpleasant feeling among individual, such as shame, guilt, fright, confusion, worthlessness, hopelessness, isolation, desperation, disappointment, sorrow, uncertainty and frustration are major reasons of committing or attempting suicide especially among young individuals (Dafoe \& Stewart, 2004). Prevention of suicide in developing countries is difficult than developed countries. Lack of resources, poverty, illiteracy, poor health system and low budget on health sector make it hard to control suicide in developing countries (Khan, 2005). The Majority of the victims, who committed suicide was male, belonged to poor families and was jobless. Among female housewives were more in number, who committed suicide. Emotional and moody people and depressed people, mostly commit suicide. This research also found the trend of committing suicide was more among illiterate and uneducated persons (Wassan, 2006).

Beautrais (2006) finds due to some factors as psychopathology and psycho-social issues being faced by women as disadvantaged gender women ratio of attempting suicide is much higher in 
women than men but ratio of suicidal deaths is higher among men. Depression is most common factor in suicide. Women having dependent children are less likely to take decision of suicide. Khan et al. (2006) analysed suicide trend in developing countries with special focus on Pakistan. In Pakistan due to many reasons as religious, cultural, legal and mistrust on police people don't report suicide. There is no accurate data available on suicide. It is hard to distinguish among homicide, suicide and accidental deaths. People hide the incidents of suicide due to harsh behaviour of police and people. Poisoning is most common method of suicide and male commits/ attempts more suicide than female. Wassan et al., (2007) suicide is a socioreligious issue. In all religions of world, it has been considered as a sin. In spite of that is prevalent in all the countries but in high rate in South Asian countries due to unemployment, domestic violence and miss-matched marriages. This paper suggests the good governance, and importance of education and role of media in controlling the suicide.

Report by WHO indicated that Pakistan has reported very less number of suicide cases in South Asian countries. In all the countries young population has more share in suicide ratio. Most common method adopted to commit suicide in all countries was hanging. In Pakistan urban areas have more ratio of suicide incidents. Comparatively suicide rate is low in Pakistan than other Asian countries due to various socio-economic and cultural factors. Pakistan is Muslim majority country (Hendin et al., 2008). Naved \& Akhter (2008) explores that ideation to commit suicide among women facing emotional and physical violence. Gearing \& Lizardi (2009) this study is descriptive in nature, research articles on religion and suicide are analysed to show the relationship between religion and suicide. Four religions are investigated and seen close connection between religiosity and suicidal rate. Dawn (2013) in its report entitled "Suicide in Thar" found joblessness, intra-family disputes, mental disorder are main causes of suicide. Ratio is more among male than female but female is also ultimate sufferer of suicide.

Lakshmi (2015) investigated the gender differentials in suicide in South Asia, especially in India. Her study found that more female are likely than male inclined to attempt suicide due to facing more psycho-social issues. Women are more vulnerable. Social, cultural, physical and emotional issues faced by women increases risk of committing/attempting suicide. Suicide is an issue which is closely related to mental health. There is need to understand the mental issues and formulating legal system accordingly (Naveed et al., 2017; Khaskheli et al., 2018). In Karachi from Jan-2014 to August-2018 total 685 cases of committing/attempting suicide were reported. Study was conducted in rural areas of six District of Sindh. Study revealed that more cases were reported from rural areas than urban areas. Rate of committing suicide is more dominating in male members. Mostly female use poisoning as a method of suicide. Suicide rate is analysed at peak in months of May, August and September. Shekhani et al. (2018) researcher found that more cases were available from urban areas, and that can be because there is lack of data on suicide in rural areas. There is dearth of official data on suicide. Religious and socio-cultural factors are main hindrances reporting cases.

In daily Dawn story on suicide in Pakistan revealed the fact that mental disorders are leading cause of suicide and poisoning is most commonly used method of committing suicide. Reports of various newspapers and data generated by HRCP found that 3500 cases were reported in 2017, 2300 in 2016 and 1900 in 2015 (Hassan, 2019). WHO Report September, 2019 considers suicide as a global issues. Both developed and developing countries are faced with this issue. In 2016 suicide was second leading cause of death of young people. Mental disorder or depression, poverty, isolation, violence, abuse and economic crises are conditions more responsible for suicide. Review of literature suggest that suicide is psycho-social issue which 
is not properly investigated in Sindh, Pakistan. Very few studies are done in this universe. Reports of newspapers indicated that in District Tharparker number of cases increasing. Researchers conducted at national or international level has found some common factors such as poverty, unemployment, failure in love ill-mental health in committing suicide. But there was no study particularly on female. This study attempts to fill this gap.

\section{Research Methodology}

The Quantitative research approach was used to collect the data form respondent in order to analyse the trend and causes of suicide among female of Nangarparkar. Purposive sampling methodology was applied and 20 cases from the universe were selected. Data were collected by structured interview from the relatives of those who committed suicide in order to know the reason of committed suicide and from those who attempted suicide. Data was analysed via SPSS version 24 and presented tables. To test the hypothesis chi square test is applied. Independent variables poverty, unemployment and failure in love and their relationship with dependant variable suicide is tested.

\section{Results and Discussion}

Table-1 shows age wise distribution of the person who committed suicide. The highest percentage that is about $50 \%$ of people who committed suicide at the age of 15-25 year. This tables indicates that trend of committing suicide is much higher in young women than older age than twenty-five years.

Table 1: Age

\begin{tabular}{|l|l|}
\hline Age in years & Percentage (\%) \\
\hline $15-25$ & 50.0 \\
\hline $26-35$ & 25.0 \\
\hline $36-45$ & 15.0 \\
\hline $46+$ & 10.0 \\
\hline Total & 100.0 \\
\hline
\end{tabular}

Sources: Primary data from field.

Table-2 envisages the education level of the person who committed suicide. About $40 \%$ of people were illiterate and $35 \%$ of people were primarily educated. The people had a high level of education the ratio of committed suicide was low.

Table 2: Educational Level

\begin{tabular}{|l|l|}
\hline Education & Percentage (\%) \\
\hline Illiterate & 40.0 \\
\hline Primary & 35.0 \\
\hline Secondary & 15.0 \\
\hline Metric & 5.0 \\
\hline Intermediate & 5.0 \\
\hline Total & 100.0 \\
\hline
\end{tabular}

Sources: Primary data from field.

Table-3 shows the marital status of people who committed suicide. About 80 percentages of people were married who committed suicide, and about $20 \%$ of people were married. It is clear from this table that married women commit more suicide than unmarried. 
Table 3: Marital Status

\begin{tabular}{|l|l|}
\hline Marital Status & Percentage (\%) \\
\hline Unmarried & 20.0 \\
\hline Married & 60.0 \\
\hline Divorced & 10.0 \\
\hline Widow & 10.0 \\
\hline Total & 100.0 \\
\hline
\end{tabular}

Sources: Primary data from field.

Table- 4 represents the employment status of the person who committed suicide.About 30 percentage of women were housewives, about 20 percent are selfemployed and also jobless and about $15 \%$ were labourer.

Table 4: Occupation

\begin{tabular}{|l|l|}
\hline Occupation & Percentage (\%) \\
\hline Self employed & 20.0 \\
\hline House wife & 30.0 \\
\hline Labourer & 15.0 \\
\hline Jobless & 20.0 \\
\hline Any other & 15.0 \\
\hline Total & 100.0 \\
\hline
\end{tabular}

Sources: Primary data from field.

Table-5 explains the health condition of a person who committed suicide. About $40 \%$ of had good health overall results show average health condition of person were good only $25 \%$ of people had poor health.

Table 5: Health Condition

\begin{tabular}{|l|l|}
\hline Health Condition & Percentage (\%) \\
\hline Good & 40 \\
\hline Average & 35 \\
\hline Poor & 25 \\
\hline Total & 100.0 \\
\hline
\end{tabular}

Sources: Primary data from field.

Table-6 reprints relation of the people who committed suicide with their parents. Overall results show they had no good relation with their parents. Large number of respondents who committed suicide had normal relationship with their parents and family members. While $30 \%$ of respondents had bad relations with parents.

Table 6: Relation with Parents

\begin{tabular}{|l|l|}
\hline Relation with parents & Percentage (\%) \\
\hline Good & 20 \\
\hline Normal & 45 \\
\hline Bad & 35 \\
\hline Total & 100.0 \\
\hline
\end{tabular}

Sources: Primary data from field.

Table-7 represents the satisfaction level of people who committed suicide. About $60 \%$ of person was not satisfied from their basic needs due to unemployment, poverty and large family 
they did not fulfil their basic needs.

Table 7: If married, were her Basic Needs satisfied?

\begin{tabular}{|l|l|}
\hline Satisfied Needs & Percentage (\%) \\
\hline Yes & 15 \\
\hline To some extent & 25 \\
\hline No & 60 \\
\hline Total & 100.0 \\
\hline
\end{tabular}

Sources: Primary data from filed.

Table- 8 envisages that about $60 \%$ of people who committed suicide were emotional. This table tells us about psychological condition of those who committed/attempted suicide. Only forty percent were emotionally stable had moderate and cool nature.

Table 8: Nature of those who Commits Suicide

\begin{tabular}{|l|l|}
\hline Nature & Percentage (\%) \\
\hline Emotional & 60 \\
\hline Moderate & 20 \\
\hline Cool & 20 \\
\hline Total & 100.0 \\
\hline
\end{tabular}

Sources: Primary data from filed.

Table-9 represents that most people committed suicide due to poverty, unemployment and socio-economic pressure as they could not support their family properly. About $40 \%$ committed suicide due to poverty which shows that poverty is a of the leading factors in suicide.

Table 9: Committed Suicide due to Poverty

\begin{tabular}{|l|l|}
\hline Due to poverty & Percentage (\%) \\
\hline Yes & 40 \\
\hline No & 35 \\
\hline Don't know & 25 \\
\hline Total & 100.0 \\
\hline
\end{tabular}

Sources: Primary from filed.

Table-10 envisages that most of the females have committed suicide due to the domestic violence. As we know due to the male dominated society female always degraded and harassed by male that is the main reason mostly female committed suicide. Domestic violence is major cause of suicide.

Table 10: Committed Suicide due to Domestic Violence

\begin{tabular}{|l|l|}
\hline Due to domestic violence & Percentage (\%) \\
\hline Yes & 55 \\
\hline No & 25 \\
\hline Don't know & 20 \\
\hline Total & 100.0 \\
\hline
\end{tabular}

Sources: Primary data from filed.

Table-11 shows the reason of committing suicide by female. About $35 \%$ of people committed suicide due to social injustice, $30 \%$ committed/attempted suicide due to mental illness and failure in love. 
Table 11: Reason of Committing/Attempting Suicide

\begin{tabular}{|l|l|}
\hline Reason & Percentage (\%) \\
\hline Failure in love & 25 \\
\hline Social injustice & 35 \\
\hline Mental illness & 30 \\
\hline Any other & 10 \\
\hline Total & 100.0 \\
\hline
\end{tabular}

Sources: Primary data from filed.

Table-12 shows a method of attempting suicide about $45 \%$ of people attempting suicide by hanging themselves and about $35 \%$ of people attempt suicide by take poison. Most common method used in committing suicide was hanging followed by poisoning and burring by $15 \%$.

Table 12: Method of Committing/Attempting Suicide

\begin{tabular}{|l|l|}
\hline Method & Percentage (\%) \\
\hline Poisoning & 35 \\
\hline Hanging & 45 \\
\hline Gun shooting & 5 \\
\hline Burning & 15 \\
\hline Total & 100.0 \\
\hline
\end{tabular}

Sources: Primary data from filed.

The following table represents the cross tabulation of reasons of committed suicide and adopted different methods of attempting suicide. About $55 \%$ of people committed suicide due to poverty by taking poison and $37 \%$ of people committed suicide due to unemployment by shooting gun. This table reveals that high percentage of people committed suicide due to poverty and failure in love by taking poising and shooting themselves by gun.

\begin{tabular}{|l|c|c|c|c|c|c|}
\hline \multicolumn{7}{|c|}{ Methods of committing/attempting suicide Cross tabulation } \\
\hline \multirow{2}{*}{ Reasons of committed suicide } & \multicolumn{7}{l|}{ Methods of committing/attempting suicide } & \multirow{2}{*}{ Total } \\
\cline { 2 - 6 } & & Hanging & Poising & Gun shooting & Burning & \\
\hline Poverty & $\%$ & 25 & 55.2 & 18.5 & 10.2 & 100.0 \\
\hline Unemployment & $\%$ & 10 & 12.5 & 37.5 & 40 & 100.0 \\
\hline Failure in Love & $\%$ & 31.2 & 43.7 & 26.5 & 11 & 100.0 \\
\hline
\end{tabular}

The result of the below table illustrates that Chi square value is 4.179 with the degree of freedom 2 with significant value 0.00 which is less 0.5 .it means most of the people committed suicide due to poverty and failure in love as compared to other reasons, the relationship between two variables is statistically significant.

\begin{tabular}{|l|c|c|c|}
\hline Chi-Square Tests \\
\hline & Value & df & Asymp. Sig. (2-sided) \\
\hline Pearson Chi-Square & $4.179^{\mathrm{a}}$ & 2 & 0.00 \\
\hline Likelihood Ratio & 5.595 & 2 & .058 \\
\hline Linear-by-Linear Association & 3.368 & 1 & .067 \\
\hline N of Valid Cases & 38 & & \\
\hline a. 3 cells (50.0\%) have expected count less than 5. The minimum expected count is 1.78. \\
\hline
\end{tabular}




\section{Conclusion}

Present research found that suicide is serious and increasing public order crime in society. Various causes of committing suicide were explored in study such as poverty, domestic violence, illiteracy or lack of education, ill health condition, and social injustice. Family environment is also one of the common reasons, as mostly those who committed suicide were not frank with parents, family was strict. Ratio of those who were married and their basic needs were not satisfied committed suicide. Hanging and poisoning methods were more frequent. Present study found that ratio of committing suicide was more high among female who were depressed, lonely and had psychological issues and social issues as domestic violence, poverty, and unemployment. Same findings were elaborated in study conducted by Wassan et al. (2006) for his $\mathrm{PhD}$ thesis entitled "Suicide in Sindh during 1995-2005: a sociological analysis". His research had similar findings as psychological condition of people who committed suicide were not stable they were emotional, depressed, and stressed. That study also found that poverty and failure in love were leading factor as revealed in current study. From statistical analysis of data is concluded that two variable were most common reason among female of Nangarpaker, District Tharpaker to commit suicide one poverty and other failure in love. Following are key recommendations of this study:

- Suicide must be recognized as a major social issue, and scholars need to work more on this topic. Especially suicide among female.

- Suicide is interlinked with other social problems of society, such as poverty, illiteracy, and domestic violence. To control the suicide rate government has to give first priority to education, eradication of poverty and domestic violence. Mentally disturbed persons should be dealt according to their nature and family members must consult psychiatrists.

- There is need to increase knowledge of psychological issues their remedies among common masses. Especially among illiterate and rural women.

\section{References}

Naved, R. T., \& Akhtar, N. (2008). Spousal violence against women and suicidal ideation in Bangladesh. Women's Health Issues, 18(6), 442-452. https://doi.org/10.1016/j.whi.2008.07.003

Beautrais, A. L. (2006). Women and suicidal behaviour. Crisis, 27(4), 153-156. https://doi.org/10.1027/0227-5910.27.4.15

Dafoe, M. E. \& Stewart, K. E. (2004). Pain and Psychiatric Disorders Contribute Independently to Suicidal Ideation in HIV-Positive Persons. Archives of Suicide Research, 8(3), 215226. https://doi.org/10.1080/13811110490436819

Gearing, R. E., \& Lizardi, D. (2008). Religion and suicide. Journal of Religion and Health, 48(3), 332-341. https://doi.org/10.1007/s 10943-008-9181-2

Hassan, T. (2019, May 13). Why Are More Pakistanis Taking Their Own Lives? DAWN. https://www.dawn.com/news/1481826

Hendin, H., Phillips, R. M., Vijaykumar, L., Pirkis,J., Wang, H. Yip, P., Wasserman, D., Bertolote M., J., Fleichmann, A. (2008). Suicide and Suicide Prevention in Asia. WHO. Retrieved from, https://apps.who.int/iris/bitstream/handle/10665/43929/9789241596893_eng.pdf 
Hawton, K. (2000). Sex and Suicide. British Journal of Psychiatry, 177(6), 484-485. https://doi.org/10.1192/bjp.177.6.484.

Khan, M. M. (2005). Suicide Prevention and Developing Countries. Journal of the Royal Society of Medicine, 98(10), 459-463. https://doi/org/10.1258/jrsm.98.10.459

Khan, M. M., \& Hyder, A. A. (2006). Suicides in the Developing World: Case Study from Pakistan. Suicide and Life-Threatening Behavior, 36(1), 76-81. https://doi.org/10.1521/suli.2006.36.1.76

Khan, M. M., \& Reza, H. (2000). The Pattern of Suicide in Pakistan. Crisis, 21(1), 31-35. https://doi.org/10.1027/0227-5910.21.1.31

Khaskheli, S. S., Perveen, S., \& Hashmi, D. (2018). Epidemiology of Reported Suicidal Attempts in Rural Areas of Sindh, Pakistan. Anaesth Pain \& Intensive Care, 22(4), 474-478. https://doi.org/10.1186/s12888-017-1586-6

Shakil, M. (2019). A Qualitative Analysis of Suicides Committed by the Students in Pakistan. Pakistan Journal of Medical Research, 58(1), 35-40.

Naveed, S., Qadir, T., Afzaal, T., \& Waqas, A. (2017, September 8). Suicide and Its Legal Implications in Pakistan: A Literature Review. Cureus. 9(9), e1965. https://doi.org/10.7759/cureus.1665

Rahma Islamic Relief. (2015). Tharparkar Situation Assesment. https://silo.tips/download/tharparkar-situation-assessment

Sindh Study Development Center. (2015). Gender and Social Vulnerability to Climate Change:A Study of Disaster Prone Areas in Sindh. https://www.preventionweb.net/publications/view/47984

Shekhani, S. S., Perveen, S., Akbar, K. Bachani, S., \& Khan, M. M. (2018). Suicide and Deliberate Self-Harm in Pakistan: A Scoping Review. BMC Psychiatry, 18(1). https://doi.org/10.1186/s12888-017-1586-6

Vijayakumar, L. (2015). Suicide in Women. Indian Journal of Psychiatry, 57(6), 233-238. https://doi.org/10.4103/0019-5545.161484

Wassan, A. (2006). Suicide in Sindh during 1991-2005: A Sociological Analysis. (Doctoral Dissertation, $\quad$ University of Sindh. http://prr.hec.gov.pk/jspui/handle/123456789/6286

Wassan, A. (2007). Suicide in Sindh: A Sociological Analysis. New Horizon Research Journal, 1(1), 15-27.

Wassan, A. A., Riaz, M., Shaikh, R., (2007). A Socio Religious Analysis of Suicides and Its Impact on Economic Development. Indus Journal of Management \& Social Science (IJMSS), 1(1), 1-13. https://ideas.repec.org/a/iih/journl/v1y2007i1p1-13.html. 